Research Article

\title{
How Long is the Safest Inter-Delivery Interval in Women with Previous History of Cesarean Delivery?
}

\author{
Berapa Lama Jarak antar Kehamilan Teraman pada \\ Perempuan dengan Riwayat Seksio Sesarea?
}

\author{
Budi I Santoso, Raymond Surya, Karina K Firdaus, Surahman Hakim \\ Department of Obstetrics and Gynecology \\ Faculty of Medicine Universitas Indonesia/ \\ Dr. Cipto Mangunkusumo Hospital \\ Jakarta
}

\begin{abstract}
Objective: To investigate the association between interdelivery interval and uterine rupture in women with previous CD.

Methods: The formulation question was how long is the safest interdelivery interval to minimalize the risk of uterine rupture. The authors investigated in three databases including Pubmed, Cochrane, and Embase database. Inclusion criteria were abstract answering the clinical question, written in English language, and full-text paper availability.

Results: One systematic review, six cohort studies, and 1 casecontrol study were collected to compare the inter-pregnancy interval to the risk of uterine rupture. The author retrieved seven articles suitable to the inclusion criteria after excluding ten articles screened by the abstract and language. Then, the author added one article used in the systematic review. Hence, the critical appraisal based on Validity, Importance, and Applicability (VIA) was performed for eight articles.
\end{abstract}

Conclusion: The inter-delivery interval $\geq 18$ months is the safest time to avoid uterine rupture. Prostaglandin analogue induction should be avoided and for patients with a history of past cesarean using a single-layer closure to be educated about the increased risk.

[Indones J Obstet Gynecol 2018; 6-2: 71-77]

Keywords: cesarean delivery, inter-delivery interval, uterine rupture, vaginal birth after cesarean delivery

\begin{abstract}
Abstrak
Tujuan: Untuk mengetahui hubungan antara jarak antar kehamilan dengan ruptur uterus pada perempuan dengan riwayat SC sebelumnya.

Metode: Formulasi pertanyaan ialah berapa lama jarak antar kehamilan teraman untuk meminimalisasi risiko ruptur uterus. Peneliti menginvestigasi dari tiga database meliputi Pubmed Cochrane, dan Embase. Kriteria inklusi ialah abstrak yang menjawab pertanyaan klinis, ditulis dalam Bahasa Inggris, dan keberadaan artikel.
\end{abstract}

Hasil: Satu ulasan sistematik, 6 studi kohort dan 1 kasus control digunakan untuk membandingkan jarak antar kehamilan dengan risiko ruptur uterus. Peneliti mengambil 7 artikel yang sesuai dengan kriteria inklusi setelah mengeksklusi 10 artikel berdasarkan abstrak dan bahasa. Peneliti menambahkan satu artikel yang terdapat di dalam ulasan sistematik. Oleh karena itu, penilaian kritis berdasarkan validitas, kepentingan, dan penerapan pada 8 artikel.

Kesimpulan: Jarak antar kehamilan $\geq 18$ bulan merupakan waktu paling aman untuk mencegah ruptur uterus. Induksi dengan analog prostaglandin sebaiknya dihindari dan pada pasien dengan riwayat SC menggunakan satu lapis sebaiknya diedukasi untuk peningkatan risiko.

[Maj Obstet Ginekol Indones 2018; 6-2: 71-77]

Kata kunci: jarak antar kehamilan, persalinan pervaginam setelah seksio sesarea, ruptur uterus, seksio sesarea

Correspondence: Raymond Surya; raymond_s130291@yahoo.co.id

\section{INTRODUCTION}

In the world, the rate of cesarean delivery (CD) has increased sharply in the last few decades from $6 \%$ to $27.2 \%$ in the most developed regions. There was an increasing trend of CD between 1990 and 2014 which the global average $\mathrm{CD}$ rate raised about $12.4 \%$ (from $6.7 \%$ to $19.1 \%$ ). ${ }^{1}$ In the United States, this rate increased from $5 \%$ in 1970 to $31 \%$ in 2007. It was related to the increasing maternal age, decreasing of instrumental deliveries usage, decreasing of vaginal delivery after previous cesarean section (VBAC), and also increasing in medically indicated labour inductions. ${ }^{2}$ American College of Obstetricians and Gynecologist (ACOG) reported that the rate of VBAC has declined from $28.3 \%$ in 1996 to $8.5 \%$ in 2006 due to the reports of increasing risk for uterine rupture and complications during VBAC. $^{3}$

Uterine rupture is the most catastrophic complication for women attempting VBAC. 4,5 The Maternal-Fetal Medicine Units (MFMU) Network Study explained the incidence of symptomatic 
uterine rupture was $0.69 \%$ of 18,000 women performing the trial of labour (TOL). ${ }^{6}$ One risk factor influencing uterine rupture is inter-delivery and inter-pregnancy interval. Short inter-delivery and inter-pregnancy have been associated with poor maternal and neonatal outcomes, such as preterm birth, low birth weight, preterm premature rupture of membranes (PPROM), placenta accrete, and uterine rupture as the worst risk. ${ }^{7}$ The pathophysiology of uterine rupture is in accordance with the healing of the lower uterine segment after CD. Short inter-delivery time causes lack of complete healing of the uterine scar which contributes to ineffective uterine contractility and poor lower segment thinning that increases the risk of uterine dehiscence or rupture. ${ }^{8}$

Therefore, the authors would like to know the association between inter-delivery interval and uterine rupture in women with previous CD. Appraisal was done with one systematic review ${ }^{9}$ and seven studies ${ }^{4,7,8,10-13}$ related to this topic to answer this evidence-based case report (EBCR). Although there were a lot of studies conducted on this topic; however, there is still no formal publication of EBCR.

The question formulation in this case report study was how long should the inter-delivery interval be to minimalize the risk of uterine rupture. To answer the question, the authors search the literature study starting from systematic review or meta-analysis as the highest hierarchy of study to expert opinion as of the lowest confidence of the study. Although this report is uncommon for scientific publication in Indonesia, the authors hope that this publication can help the obstetrics and gynecologists to improve their practice.

\section{Case Resume}

In this case, a 33-year-old female P1A0 came for the routine postpartum control. The patient preferred vaginal birth in that pregnancy; however, the obstetrician findings of oligohydramnios and post-term pregnancy suggested to CD. After CD, the obstetrician did the double-layer uterine closure. Now, the patient plans to get pregnant again because of her age; but she still intends to give exclusive breastfeeding. She asked the doctor how long she should postpone before the next pregnancy and whether she can deliver vaginally for the next pregnancy.
The patient asked herself what was the minimal inter-delivery interval that has minimal risk of uterine rupture. Through some searching, the patient heard that World Health Organization (WHO) recommends 24 months as the safe interdelivery interval, but she was not satisfied with the information yet. Therefore, to gather the most appropriate inter-delivery interval in women with a history of $C D$, the authors conduct five steps of EBCR, consisting of formulation of the question, searching the evidence, appraisal of the study, applying the answer, and assessing the outcome.

\section{Formulation of the question}

How long is the minimal inter-delivery interval to minimize the risk of uterine rupture?

\section{Searching the evidence}

To answer the practical question above, three databases were investigated including PubMed, Cochrane database, and Embase database. In PubMed, the search included keywords using the $\mathrm{MeSH}$, namely ("Birth Intervals"[Mesh] AND "Uterine Rupture"[Mesh]) and MeSH descriptor: [Birth Intervals] AND MeSH descriptor: [Uterine Rupture] in Cochrane database. Meanwhile, the authors used the keywords "uterine rupture" AND "inter-pregnancy interval" in Embase. All studies related to this topic were accepted due to the lack of systematic review or meta-analysis. Finally, 11 articles were found in PubMed, 1 article in Cochrane database, and ten articles in Embase. The articles were screened using the criteria consisting of abstracts answering the clinical question, written in English language, full-text paper availability, and omitting all duplication papers. Therefore, from this strategy of searching, the authors obtained one systematic review and six articles that continued to the next process of appraisal. The critical appraisal steps used in this article was written by Agustin CA et al. ${ }^{9}$; Emmanuel B, et al. ${ }^{7}$ Emmanuel B, et al. ${ }^{4}$ Roy $\mathrm{K}$, et al. ${ }^{10}$; Thomas DS, et al. ${ }^{11}$; David MS, et al. ${ }^{12}$, Matthew AE, et al. ${ }^{13}$ Due to lack of inconsistency in the appraisal of systematic review, all studies were reviewed and recruited by the systematic review. The authors found one study that was not included in the strategy of searching the evidence. Therefore, the authors included the study by Wilson $\mathrm{HH}$ et al. into our appraisal (described in figure 1). 
One systematic review and ten articles (PubMed)
One article

(Cochrane database)

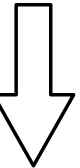

Two systematic reviews and 19 articles

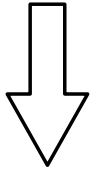

One systematic review and ten articles (PubMed)

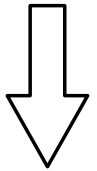

One systematic review and six articles<smiles>C1CCCCC1</smiles>

One systematic review and seven articles
One systematic review and nine articles (Embase)

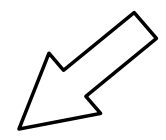

One systematic review and three articles had the same title

Ten articles were excluded by screening the abstract and language ( 1 article was written in French and another one in the Arabic language)

One article was included in appraisal from the systematic review

Figure 1. Flowchart of selecting articles using in EBCR

\section{Appraisal of the studies}

To appraise the scientific evidence of 8 articles, the guideline from Consolidated Standard of Reporting Trials (CONSORT) for retrospective studies and A Measurement Tool to Assess Systematic Reviews
(AMSTAR) for systematic review was used. The tables 1, 2, and 3 below describe the appraisal form from the study based on VIA (validity, importance, and applicability) methods. 
Table 1. Validity of the Studies Included in the Analysis**

\begin{tabular}{|c|c|c|c|c|c|c|c|c|c|}
\hline Study & $\begin{array}{l}\text { Type } \\
\text { of study }\end{array}$ & $\begin{array}{l}\text { Focused } \\
\text { research } \\
\text { question }\end{array}$ & $\begin{array}{c}\text { Selection } \\
\text { criteria }\end{array}$ & $\begin{array}{l}\text { Primary } \\
\text { outcome }\end{array}$ & $\begin{array}{c}\text { Number } \\
\text { of } \\
\text { studies }\end{array}$ & $\begin{array}{l}\text { Number } \\
\text { of } \\
\text { subjects }\end{array}$ & $\begin{array}{l}\text { Validity } \\
\text { appraisal }\end{array}$ & $\begin{array}{l}\text { Reliability } \\
\text { assessment }\end{array}$ & $\begin{array}{l}\text { Similarity of } \\
\text { the studies } \\
\text { (homogeneity) }\end{array}$ \\
\hline Conde-Agudelo A, et al & $\begin{array}{l}\text { Systematic } \\
\text { review }\end{array}$ & Yes & Yes & $\begin{array}{l}\text { Uterine } \\
\text { rupture }\end{array}$ & 4 & 5164 & Yes & No & Not mentioned \\
\hline Bujold E, et al & $\begin{array}{l}\text { Research } \\
\text { article }\end{array}$ & Yes & Yes & $\begin{array}{l}\text { Uterine } \\
\text { rupture }\end{array}$ & & 1527 & & & \\
\hline Bujold E, et al & $\begin{array}{l}\text { Research } \\
\text { article }\end{array}$ & Yes & Yes & $\begin{array}{l}\text { Uterine } \\
\text { rupture }\end{array}$ & & 1768 & & & \\
\hline Kessous R, et al & $\begin{array}{l}\text { Research } \\
\text { article }\end{array}$ & Yes & Yes & $\begin{array}{l}\text { Pregnancy complications } \\
\text { and adverse outcomes }\end{array}$ & & 3176 & & & \\
\hline Shipp TD, et al & $\begin{array}{l}\text { Research } \\
\text { article }\end{array}$ & Yes & Yes & $\begin{array}{l}\text { Uterine } \\
\text { rupture }\end{array}$ & & 2409 & & & \\
\hline Stamilio DM, et al & $\begin{array}{l}\text { Research } \\
\text { article }\end{array}$ & Yes & Yes & $\begin{array}{l}\text { Uterine rupture, composite } \\
\text { major morbidity, and } \\
\text { blood transfusion }\end{array}$ & & 13331 & & & \\
\hline Huang $\mathrm{WH}$, et al & $\begin{array}{l}\text { Research } \\
\text { article }\end{array}$ & Yes & Yes & The rate of successful VBAC & & 1185 & & & \\
\hline Eposito MA, et al & $\begin{array}{l}\text { Research } \\
\text { article }\end{array}$ & Yes & Yes & & 43 & & & & \\
\hline
\end{tabular}

Table 2. Importance of the Studies Included in the Analysis

\begin{tabular}{llc}
\hline \multicolumn{1}{c}{ Study } & Overall results (treatment preference) & 95\% CI \\
\hline Conde-Agudelo A, et al & $\begin{array}{l}\text { Long intervals (birth intervals } \geq 19 \text { or } 25 \text { months and interpregnancy } \\
\text { interval } \geq 6 \text { months) }\end{array}$ & Not mentioned \\
Bujold E, et al & Interdelivery interval $>24$ months & 2.65 \\
Bujold E, et al & Interdelivery interval $\geq 18$ months & 2.8 \\
Kessous R, et al & Not significant difference among $\leq 12,13-18,19-24, \geq 25$ months \\
Shipp TD, et al & Interdelivery interval $>18$ months & $1.2-6.6$ \\
Stamilio DM, et al & Interpregnancy interval $\geq 6$ months & 3.46 \\
Huang WH, et al & Not significant difference between $<19$ and $\geq 19$ months & $1.21-5.82$ \\
Eposito MA, et al & Interpregnancy interval $\geq 6$ months & 2.66 \\
\hline \hline
\end{tabular}

Table 3. Applicability of the Studies Included in the Analysis

\begin{tabular}{|c|c|c|c|c|}
\hline Study & The source of data & $\begin{array}{l}\text { Apply the } \\
\text { result to } \\
\text { patient care }\end{array}$ & $\begin{array}{l}\text { Considering } \\
\text { all clinically } \\
\text { important } \\
\text { outcomes }\end{array}$ & $\begin{array}{l}\text { Other clinical outcome (s) } \\
\text { or risk factor }(s)\end{array}$ \\
\hline Conde-Agudelo A, et al & 3 cohort and 1 case-control studies & Yes & Yes & \\
\hline Bujold E, et al & $\begin{array}{l}\text { Sainte-Justine Hospital, } \\
\text { Montreal, Canada }\end{array}$ & Yes & Yes & $\begin{array}{l}\text { Single-layer uterine closure at the previous CD (OR 4.33; } 95 \% \text { CI } \\
1.70-10.98) \text { increased the risk of uterine rupture }\end{array}$ \\
\hline Bujold E, et al & $\begin{array}{l}\text { Sainte-Justine Hospital, } \\
\text { Montreal, Canada }\end{array}$ & Yes & Yes & $\begin{array}{l}\text { Previous single-layer closure (OR 7.5; 95\% CI 3.2-17.6) } \\
\text { increased the risk of uterine rupture }\end{array}$ \\
\hline Kessous R, et al & $\begin{array}{l}\text { Soroka University Medical Center, } \\
\text { Southern region of Israel }\end{array}$ & Yes & Yes & $\begin{array}{l}\text { Long inter-delivery interval more than } 24 \text { months had higher } \\
\text { rate of gestational diabetes mellitus and higher rates of CD; } \\
\text { short interval group had lower birth weight and higher } \\
\text { prevalence of low Apgar score at } 1 \text { and } 5 \text { minutes }\end{array}$ \\
\hline Shipp TD, et al & $\begin{array}{l}\text { Brigham and Women's Hospital, } \\
\text { Massachusetts, USA }\end{array}$ & Yes & Yes & $\begin{array}{l}\text { Induced with oxytocin (OR 4.9; } 95 \% \text { CI 1.7-14.6) } \\
\text { increased the risk of uterine rupture }\end{array}$ \\
\hline Stamilio DM, et al & $\begin{array}{l}\text { Seventeen Hospitals in the } \\
\text { Northeastern, USA }\end{array}$ & Yes & Yes & $\begin{array}{l}\text { Interpregnancy interval }<6 \text { months had higher risk for } \\
\text { composite morbidity (OR 1.95; 95\% CI 1.04-3.65) and } \\
\text { blood transfusion (OR 3.14; 95\% CI 1.42-6.95) }\end{array}$ \\
\hline Huang WH, et al & $\begin{array}{l}\text { Irvine and Long Beach Memorial } \\
\text { Medical Center, California, USA }\end{array}$ & Yes & Yes & \\
\hline Eposito MA, et al & $\begin{array}{l}\text { Women and Infants' Hospital, } \\
\text { Rhode Island, USA }\end{array}$ & Yes & Yes & \\
\hline
\end{tabular}




\section{Applying the answers}

Inter-delivery interval has been associated with obstetric outcomes; one of them is the uterine rupture in women with previous history of CD. Report of WHO Technical Consultation on Birth Spacing in 2005 recommended the interpregnancy interval was at least 24 months to reduce the risk of adverse maternal, perinatal, and infant outcomes. This interval was consistent with the recommendation of breastfeeding for two years. Apart from that, WHO considered 2 years as the number which easily remembered in the program rather than "18 months" or "27 months".14 Meanwhile, the Society of Obstetricians and Gynecologist of Canada (SOGC) in 2005 stated that inter-delivery interval more than 18 months had the lowest risk factor for uterine rupture. ${ }^{15}$ The differences between the guidelines are the reason of interest related to searching of the evidence about the association between inter-delivery interval and the risk of uterine rupture. Apart from that, patients always ask the doctor for the minimal inter-delivery interval that is safe for the next pregnancy in women with history of CD. Therefore, this interval becomes our concern to answer the practical questions.

In this EBCR, one systematic review, six cohort studies, and 1 case-control study were collected to compare the inter-pregnancy interval to the risk of uterine rupture. The authors retrieved seven articles suitable to the inclusion criteria after excluding ten articles screened by the abstract and language. Then, one article was used in the systematic review, so this critical appraisal based on VIA was performed for eight articles.

Systematic review by Conde-Agudelo A, et al. ${ }^{9}$ involved 3 cohort studies and 1 case-control study presented that there was an increasing risk of uterine rupture in women with short interval, whereas short birth interval in the study was defined as less than 19 or 25 months or interpregnancy interval was less than six months. Meanwhile, in one cohort study in the systematic review did not find an association between interdelivery interval and uterine rupture. Due to lack of reliability assessment in the systematic review, all studies included in Agustin CA study were searched.

The authors found similar results among studies conducted by Bujold E, et al. ${ }^{7}$, Bujold E, et al. ${ }^{4}$, Shipp TD, et al. ${ }^{11}$, Stamilio DM, et al. ${ }^{12}$, and Eposito
MA, et al. ${ }^{13}$ They concluded that short interdelivery interval was associated with the increased risk of uterine rupture; however, the definition of short interval was different among those studies. Bujold E, et al. ${ }^{7}$ in their study showed that single-layer closure and inter-delivery interval $\leq 24$ months significantly increased the risk of uterine rupture. Therefore, single-layer closure (OR 4.33; 95\% CI 1.70-10.98) and inter-delivery interval $\leq 24$ months (OR 2.65; 95\% CI 1.08-5.46) were two independent factors related to uterine rupture. In this study, the use of prostaglandin during labor was very low $(<1 \%)$. It is very essential because the use of it has been shown as significant factor associated with uterine rupture. In later study by Bujold E, et al. ${ }^{4}$ explained the similar results to a previous study where inter-delivery interval less than 18 months (OR 2.8; 95\% CI 1.2-6.6) and single-layer closure (OR 7.5; 95\% CI 3.2-17.6) were factors contributed to uterine rupture. The difference between this and previous study was in the inter-delivery interval limitation. In the later study, they found that the 18 months of interdelivery interval was enough to minimalize the risk of uterine rupture. This study described a similar result to a study by Shipp TD, et al. ${ }^{11}$ They concluded that inter-delivery interval $\leq 18$ months (OR 3.0; 95\% CI 1.2-7.2) and induced with oxytocin (OR 4.9; 95\% CI 1.7-14.6) were associated with the risk of uterine rupture. Meanwhile, Stamilio DM, et al. ${ }^{12}$ and Eposito MA, et al. ${ }^{13}$ used the interpregnancy interval term rather than inter-delivery interval. Stamilio DM, et al. ${ }^{12}$ explained that short inter-pregnancy interval of fewer than 6 months increased the risk for uterine rupture in patients attempted the VBAC (OR 2.66; 95\% CI 1.21-5.82), composite morbidity (OR 1.95; 95\% CI 1.04-3.65), and blood transfusion (OR 3.14; 95\% CI 1.42-6.95). This study also revealed that patients with short inter-pregnancy interval had lower haemoglobin level on average, was younger, and was less likely to develop gestational diabetes and chronic hypertension. This study also stated finding literature concluding radiographic and hysteroscopic evidence that cesarean scar development is incomplete for as long as 6 or 12 months postoperatively. While, in the case-control study by Eposito MA, et al. ${ }^{13}$, the risk of uterine rupture increased in patients with inter-pregnancy interval $<6$ months (OR 3.92; 95\% CI 1.09-14.3).

Unfortunately, studies by Kessous R, et al. ${ }^{10}$ and Wilson $\mathrm{HH}$, et al. both showed different results 
from above. Both studies did not express association between inter-delivery interval and risk of uterine rupture. Kessous $\mathrm{R}$, et al. ${ }^{10}$ stated that the risk of uterine rupture did not differ between the inter-delivery interval of less than 18 months and more than 19 months ( $\mathrm{p}=0.131)$. This study only presented that short interval group had higher rates of preterm deliveries, lower birth weight, and prevalence of low Apgar score at 1 and 5 minutes. Huang $\mathrm{WH}$, et al. similarly concluded that the difference between the group with inter-delivery interval greater and less than 19 months was not related to the symptomatic uterine rupture $(\mathrm{p}=1.00)$.

In Indonesia, there is still no consensus regarding VBAC and the minimal inter-delivery interval to reduce the risk of uterine rupture. Meanwhile, ACOG explained that most women with one previous cesarean delivery with a lowtransverse incision should be counselled for the VBAC and offered the TOLAC. Misoprostol as prostaglandin analogue should not be used for the cervical ripening or labour induced patients with history of CD or major uterine surgery. ${ }^{3}$ The guideline by Royal College of Obstetricians and Gynecologists (RCOG) states that planned VBAC is appropriate for the majority of women with singleton pregnancy of cephalic presentation at $37^{+0}$ weeks or beyond with a single previous lower segment cesarean delivery. However, VBAC is contraindicated in women with previous uterine rupture or classical cesarean scar and in women who have other absolute contraindications to vaginal birth such as major placenta previa. The success rate of planned VBAC reaches $72-75 \%$. Before offering the TOLAC, the clinician has to make the individual assessment of the risk of uterine rupture. ${ }^{16}$ One of the main factors is inter-delivery interval.

After appraising the studies conducted in some countries (USA, Israel, and Canada), two studies mentioned the safe inter-delivery interval more than 18 months, two studies concluded the safe inter-pregnancy interval more than six months, and the other one said inter-delivery interval should be more than 24 months. The mother has enough time to complete exclusive breastfeeding for six months although the WHO suggests that the breastfeeding should be continued up to 2 years. The authors recommend taking interpregnancy interval a minimum 18 months based on the two cohort studies done by Bujold E, et al. and Shipp TD, et al. Another reason for using 18 months as the cut-off is the finding of Stamilio DM, et al. that hysteroscopic and radiographic evidence stating incomplete scar healing 6-12 months. Hence, inter-delivery of 18 months is enough for a minimum complete scar healing. Nevertheless, the other factors which impact to increase the risk of uterine rupture are single-layer closure and oxytocin induction. In this era of National Health Coverage (Jaminan Kesehatan Nasional/JKN) in Indonesia, patients should be offered the TOLAC and VBAC if the requirement of minimal interdelivery interval is fulfilled. Vaginal birth is surely more cost-effective and efficient than CD. In conclusion, when doing the counselling, the clinician should advise the TOLAC and VBAC regarding minimal inter-delivery interval and history of double-layer uterine closure to minimize the morbidity of uterine rupture.

\section{Assessing the outcomes}

Our patient would like to get pregnant as soon as possible because of her age and desired vaginal birth. Based on guideline by ACOG and RCOG, the patient with history of low-transverse incision in previous cesarean delivery can do the TOLAC and VBAC. Even, the success rate of TOLAC and VBAC in that condition reached $72-75 \%$. But, the interdelivery interval has to be considered to reduce the risk of uterine rupture. After doing the appraisal, the authors suggest that equal or more than 18 months of inter-delivery interval is enough to have the minimal risk of uterine rupture. The hypothesis to explain the relationship between short interval and risk of uterine rupture is that the scar requires minimal time to heal from reaching the full strength. To support this statement, a study done by Dicle 0 , et al. ${ }^{17}$ reported that the zonal anatomy of uterus needed minimally six months to get back completely. Like stated before, Stamilio DM et al also found a similar finding but with a larger range of duration whereas through hysteroscopic and radiographic evidence it was stated that incomplete scar healing ranging from 6 to 12 months. Hence, inter-delivery of 18 months is enough for a minimum complete scar healing and also for completing exclusive breastfeeding for 6 months.

If the authors look at the neonatal outcome, Kessous R, et al. ${ }^{10}$ said that short inter-delivery interval was associated with preterm labor, lower 
birth weight, and higher prevalence of low Apgar score at 1 and 5 minutes. Low Apgar score impacts the neonatal outcome which can end in morbidity and even mortality. The history of double-layer uterine closure would minimalize the risk of uterine rupture because study conducted in Canada revealed the risk of it was increased in the previous single-layer closure. ${ }^{4,7}$

In this EBCR, the authors reported a woman with history of $C D$ asking for the minimal interval for the second pregnancy to do the vaginal birth in the next pregnancy. In the previous $C D$, the doctor did the double-layer uterine closure. From this critical appraisal focused on one systematic review and seven articles collected from PubMed, Cochrane database, and Embase with specific criteria, the authors could summarise that the inter-delivery interval more than 18 months has the minimal risk of uterine rupture regarding the history of double-layer closure. Apart from that, for the next pregnancy, it is not recommended to be induced by misoprostol as the prostaglandin analogue. In conclusion, for the patient above, the authors advise minimal 18 months for next delivery and offer the TOLAC for the cost-effective and efficient in the era of JKN with considering the minimal risk of uterine rupture.

\section{CONCLUSION}

Based on evidence, the inter-delivery interval $\geq 18$ months is the safest time to avoid uterine rupture. Prostaglandin analogue induction should be avoided and for patients with a history of past cesarean using a single-layer closure to be educated about the increased risk.

\section{Conflict of Interest}

The authors hereby declare that there is no conflict and financial interest in this EBCR study.

\section{Acknowledgement}

The authors would like gratitude to all people who have supported from preparing to writing this manuscript. The authors confirm that the funding in this appraisal is pure from personal account.

\section{REFERENCES}

1. Betrán AP, Ye J, Moller A-B, Zhang J, Gülmezoglu AM, Torloni MR. The Increasing Trend in Caesarean Section Rates: Global, Regional and National Estimates: 1990-2014. PLoS One [Internet]. 2016;11(2):e0148343. Available from: http://www.pubmedcentral.nih.gov/articlerender.fcgi?art $\mathrm{id}=4743929 \&$ tool $=$ pmcentrez\&rendertype $=$ abstract

2. MacDorman M, Declercq E, Menacker F. Recent Trends and Patterns in Cesarean and Vaginal Birth After Cesarean (VBAC) Deliveries in the United States. Clin Perinatol. 2011; 38(2): 179-92.

3. American College of Obstetricians and Gynecologists. Vaginal birth after previous cesarean delivery. Obstet Gynecol. 2010; 116(2 Pt 1): 450-63.

4. Bujold E. Risk of Uterine Rupture Associated with an Interdelivery Interval between 18 and 24 Months. 2010; 115(5): 1003-6.

5. Landon MB. Predicting Uterine Rupture in Women Undergoing Trial of Labor After Prior Cesarean Delivery. YSPER [Internet]. 2010; 34(4): 267-71. Available from: http://dx.doi.org/10.1053/j.semperi.2010.03.005

6. Saglio G, Wook Kim D, Issaragrisil S, Courtre P le, Etienne G, Lobo C, et al. N Engl J Med. 2010; 362(24): 2251-9.

7. Bujold E, Mehta SH, Bujold C, Gauthier RJ. Inter-delivery interval and uterine rupture. Am J Obstet Gynecol. 2002; 187(5): 1199-202.

8. Huang WH, Nakashima DK, Rumney PJ, Keegan KA, Chan $\mathrm{K}$. Interdelivery interval and the success of vaginal birth after cesarean delivery. Obstet Gynecol. 2002; 99(1): 41-4.

9. Conde-agudelo A, Rosas-bermúdez A, Kafury-goeta AC. Effects of birth spacing on maternal health?: a systematic. Am J Obstet Gynecol. 2007; 196(4): 297-308.

10. Kessous R, Sheiner E. Is there an association between short interval from previous cesarean section and adverse obstetric and perinatal outcome? J Matern Fetal Neonatal Med. 2013; 26(10): 1003-6.

11. Shipp TD, Zelop CM, Repke JT, Cohen A, Lieberman E. Interdelivery interval and risk of symptomatic uterine rupture. Obstet Gynecol. 2001; 97(2): 175-7.

12. Delivery C. Short Interpregnancy Interval. 2007; 110(5): 1075-82.

13. Esposito MA, Menihan CA, Malee MP. Association of interpregnancy interval with uterine scar failure in labor?: A case-control study. 2000;1180-3.

14. World Health Organization. Report of a WHO Technical Consultation on Birth Spacing. [downloaded at Feb $8^{\text {th }}$ 2017]. 2005. Available from: http://www.who.int/maternal_child_adolescent/documents/birth_spacing05/en/

15. Martel MJ, MacKinnon CJ. Canada CPOC of the S of O and G of guidelines for vaginal birth after previous Caesarean birth. J Obstet Gynaecol Can. 2004; 26(7): 660-6.

16. Royal College of Obstetricians \& Gynecologists. Birth After Previous Caesarean Birth. Green-top Guideline. 2015: 45.

17. Dicle O, Küçükler C, Pirnar T, Erata Y, Posaci C. Magnetic resonance imaging evaluation of incision healing after cesarean sections. Eur Radiol. 1997; 7(1): 31-4. 